\title{
The larger bronchi in byssinosis: a morphometric study
}

\author{
C EDWARDS, A CARLILE, G ROOKE
}

From the Department of Pathology, East Birmingham Hospital, Bordesley Green East, Birmingham B9 5ST, and the Pneumoconiosis Medical Panel, Manchester

SUMMARY The proportions of gland, muscle and cartilage were measured in the named bronchi of 43 byssinotics, and compared with the proportions in normal subjects and chronic bronchitics. The smoking habits and symptomatology of the byssinotics were also investigated.

In the byssinotics the proportions of gland, muscle and cartilage were higher than in the normal, non-smoking subject at all levels in the bronchial tree, and were similar to those in chronic bronchitics. The increase was not confined to the lobar bronchi as the results of a previous investigation had suggested. It is concluded that although exposure to cotton dust is a factor in the pathogenesis of chronic byssinosis, anatomical changes in the bronchi of Lanchashire cotton workers are non-specific, and are confounded by other environmental factors.

Smoking has a deleterious effect on the natural history of the disease, but no morphological difference between smokers and non-smokers was found.

Byssinosis is a chronic respiratory disease of workers employed in the processing of natural fibres. After some years in the industry, the patient complains of chest tightness on return to work after a weekend or a holiday. In the early stages the symptoms clear within $24 \mathrm{~h}$, but later they recur on the second and subsequent days of the working week. Eventually there may be permanent respiratory disability, but the first day of the week is always the worst. ${ }^{1}$

In Britain byssinosis has been a recognised industrial disease since 1941. For the purposes of compensation the following clinical grading is generally used. ${ }^{1}$

Grade $\frac{1}{2}$ Occasional chest tightness on the first day of the working week.

Grade 1 Chest tightness on every first day of the working week.

Grade 2 Chest tightness on first and other days of the working week.

Grade 3 Grade 2 symptoms accompanied by evidence of permanent incapacity from diminished effort tolerance and/or reduced ventilatory capacity. At the time of writing a claimant must have at least grade 2 symptoms, and must have worked in the cardroom, or in the spinning, beaming or winding areas.

In 1975 we published an account of the postmortem changes in the lungs and hearts of a group of byssinotic subjects. ${ }^{2}$ The results suggested that there was

Accepted for publication 15 September 1983 an increase in the proportion of smooth muscle and gland in the lobar bronchi, but not in segmental bronchi. No specific abnormalities were found in the lung parenchyma or vasculature, and there was no evidence of an increased incidence of pulmonary or systemic hypertension. Later, Pratt and his coworkers ${ }^{3}$ found that there was a relation between bronchial glandular hyperplasia and cotton dust exposure in mill operatives in North Carolina.

This paper deals with a detailed morphometric analysis of the named bronchi of the left lung in 43 byssinotics from Oldham, Lancashire. The changes are compared with those found in chronic bronchitis.

\section{Material and methods}

Three groups were studied (Table 1). The first consisted of 43 patients from Oldham who had been receiving industrial benefit for byssinosis. Details of their smoking habits and industrial histories are given in Table 2 . The second and third groups were patients

Table 1 Number, sex, age range and mean in the three groups

\begin{tabular}{lcccc}
\hline Group & Sex & $\begin{array}{l}\text { Age range } \\
\text { (yr) }\end{array}$ & $\begin{array}{l}\text { Age mean } \\
(\mathrm{yr})\end{array}$ \\
\hline $\begin{array}{l}\text { Byssinotics } \\
\text { Birmingham } \\
\text { normals }\end{array}$ & 19 & 24 & $48-87$ & $71 \cdot 3$ \\
$\begin{array}{l}\text { Birmingham } \\
\text { chronic bronchitics }\end{array}$ & 15 & 3 & $37-85$ & 64.9 \\
\hline
\end{tabular}


Table 2 Mean periods (in yr) of total cotton dust exposure, first exposure to onset of symptoms, duration of disease and age at death. Three subjects have been excluded because of lack of information

\begin{tabular}{|c|c|c|c|c|c|}
\hline & Exposure & Onset & Duration & $\begin{array}{l}\text { Age } \\
(y r)\end{array}$ & No. \\
\hline All & $\begin{array}{c}32 \cdot 6 \\
(10 \cdot 6)\end{array}$ & $\begin{array}{c}29.4 \\
(11.8)\end{array}$ & $\begin{array}{c}24.9 \\
(9.0)\end{array}$ & $\begin{array}{l}71 \cdot 3 \\
(9 \cdot 4)\end{array}$ & 40 \\
\hline Male & $\begin{array}{c}31.4 \\
(11.6)\end{array}$ & $\begin{array}{c}27.8 \\
(12.0)\end{array}$ & $\begin{array}{c}26 \cdot 1 \\
(11 \cdot 7)\end{array}$ & $\begin{array}{l}70.8 \\
(9.1)\end{array}$ & 18 \\
\hline Female & $\begin{array}{c}33.6 \\
(10 \cdot 2)\end{array}$ & $\begin{array}{c}30 \cdot 8 \\
(12 \cdot 1)\end{array}$ & $\begin{array}{c}24.0 \\
(6.6)\end{array}$ & $\begin{array}{c}71.7 \\
(10.1)\end{array}$ & 22 \\
\hline Smokers & $\begin{array}{c}30 \cdot 9 \\
(11 \cdot 2)\end{array}$ & $\begin{array}{l}27 \cdot 3 \\
(11.9)\end{array}$ & $\begin{array}{c}24 \cdot 9 \\
(10 \cdot 2)\end{array}$ & $\begin{array}{c}68.8 \\
(8.9)\end{array}$ & 30 \\
\hline Non-smokers & $\begin{array}{l}37.9 \\
(6 \cdot 8)\end{array}$ & $\begin{array}{l}35 \cdot 8 \\
(9 \cdot 3)\end{array}$ & $\begin{array}{c}25 \cdot 0 \\
(4 \cdot 2)\end{array}$ & $\begin{array}{l}78 \cdot 8 \\
(6 \cdot 8)\end{array}$ & 10 \\
\hline Female smokers & $\begin{array}{c}30.0 \\
(10.9)\end{array}$ & $\begin{array}{c}25 \cdot 7 \\
(12 \cdot 7)\end{array}$ & $\begin{array}{l}23.9 \\
(8.3)\end{array}$ & $\begin{array}{c}67 \cdot 4 \\
(10 \cdot 0)\end{array}$ & 13 \\
\hline $\begin{array}{l}\text { Female } \\
\text { non-smokers } \\
\text { Male smokers }\end{array}$ & $\begin{array}{c}38 \cdot 8 \\
(6 \cdot 6) \\
31 \cdot 5 \\
(12 \cdot 0)\end{array}$ & $\begin{array}{c}38 \cdot 1 \\
(6 \cdot 1) \\
28 \cdot 5 \\
(11 \cdot 9)\end{array}$ & $\begin{array}{c}24 \cdot 1 \\
(3 \cdot 4) \\
25 \cdot 7 \\
(11 \cdot 9)\end{array}$ & $\begin{array}{l}77 \cdot 9 \\
(6 \cdot 5) \\
69 \cdot 8 \\
(8 \cdot 5)\end{array}$ & 17 \\
\hline $\begin{array}{l}\text { Male } \\
\text { non-smokers }\end{array}$ & 30 & 15 & 30 & 87 & 1 \\
\hline
\end{tabular}

Standard deviations are shown in parentheses.

from Birmingham, and consisted respectively of five patients who had died suddenly, were non-smokers, and had no clinical or postmortem evidence of respiratory disease, and 18 chronic bronchitics.

In each case the lungs were distended with formol saline and fixed for at least $48 \mathrm{~h}$. The percentages of gland, muscle and cartilage in transverse sections of the named bronchi were estimated using an electronic planimeter as previously described. ${ }^{45}$

\section{Results}

\section{MOR PHOMETR Y}

The percentages of the tissue components in individual bronchi are shown in Table 3. More detailed analyses of the figures for the normals and the chronic bronchitics are given elsewhere. ${ }^{5}$ In the present context it is sufficient to say that in the chronic bronchitics the percentages of gland and muscle were higher than in the normal subjects at all sites, and at some sites the percentage of cartilage was also increased.

\section{Comparison of byssinotics and normal subjects}

From Table 3 it can be seen that the percentages of all the components in the byssinotics were higher than in the normal subjects at all sites $(p<0.005-0.001)$, with the exception of the cartilage of the main left bronchus.

\section{Comparison of byssinotics and chronic bonchitics}

In the chronic bronchitics the percentage of muscle was significantly less than in the byssinotics at most sites, and the percentage of gland was significantly higher in the main and upper lobe bronchi. The percentage cartilage in the segmental bronchi of the chronic bronchitics was significantly less than in the byssinotics.

Although statistically significant, in practical terms the differences were small, and there was considerable overlap between the two groups. It was not possible to distinguish individual patients with byssinosis from those with chronic bronchitis on morphological or morphometric grounds.

The byssinotics: tissue proportions at different sites in the bronchial tree

Within the byssinotic group, cartilage content varied from site to site. The upper lobe bronchus contained significantly more cartilage than any other $(p<0.05)$, and the main left bronchus contained significantly more cartilage than the lower lobe bronchus $(p<0.05)$, which in turn contained significantly more cartilage than the segmental bronchi $(p<0.005)$. Cartilage contents of the upper and lower lobe segmental bronchi did not differ.

The proportions of gland in the lower lobe bronchus and the upper segmental bronchi were both significantly higher than in the lower segmental bronchi $(p<0.0025)$. The proportion of muscle in the lower lobe bronchus was significantly greater than at any other site $(\mathrm{p}<0.01)$, and the proportion in the

Table 3 The figures are mear percentages of the three components of the bronchial walls in byssinotics, normal subjects and chronic bronchitics. Figures for the control groups are marked by an asterisk where they differ significantly from the byssinotics $(p<0.05)$.

\begin{tabular}{|c|c|c|c|c|c|c|c|c|c|}
\hline & \multicolumn{3}{|c|}{ Cartilage (\%) } & \multicolumn{3}{|l|}{ Gland $(\%)$} & \multicolumn{3}{|l|}{ Muscle (\%) } \\
\hline & Byssinotics & $N$ & $C B$ & Byssinotics & $N$ & $C B$ & Byssinotics & $N$ & $C B$ \\
\hline \multirow{3}{*}{$\begin{array}{l}\text { Left main bronchus } \\
\text { Upper lobe bronchus } \\
\text { Lower lobe bronchus } \\
\text { Upper lobe segmental } \\
\text { bronchi } \\
\text { Lower lobe segmental } \\
\text { bronchi }\end{array}$} & $\begin{array}{l}39 \cdot 4 \\
42 \cdot 7 \\
36 \cdot 2\end{array}$ & $\begin{array}{l}42 \cdot 3 \\
39 \cdot 3^{*} \\
25 \cdot 1^{*}\end{array}$ & $\begin{array}{l}44 \cdot 0 \\
37 \cdot 6 \\
34 \cdot 3\end{array}$ & $\begin{array}{l}15.5 \\
15.9 \\
17.1\end{array}$ & $\begin{array}{l}6 \cdot 7^{*} \\
8 \cdot 4^{*} \\
8 \cdot 0^{*}\end{array}$ & $\begin{array}{l}19 \cdot 2^{*} \\
20 \cdot 2^{*} \\
16 \cdot 2\end{array}$ & $\begin{array}{l}2.9 \\
2.0 \\
3.7\end{array}$ & $\begin{array}{l}1.0^{*} \\
0.7^{*} \\
1.5^{*}\end{array}$ & $\begin{array}{l}2 \cdot 2^{*} \\
2 \cdot 0 \\
2 \cdot 6^{*}\end{array}$ \\
\hline & $33 \cdot 2$ & $20 \cdot 3^{*}$ & $25 \cdot 8^{*}$ & $16 \cdot 7$ & $6 \cdot 1^{*}$ & $16 \cdot 4$ & 2.0 & $0.6^{*}$ & $1.4^{*}$ \\
\hline & $29 \cdot 8$ & $23.9 *$ & $25.9 *$ & $14 \cdot 4$ & $6 \cdot 2^{*}$ & 15.9 & 1.9 & $0.6^{*}$ & $1.4^{*}$ \\
\hline
\end{tabular}

$\mathrm{N}=$ normal subject; $\mathbf{C B}=$ chronic bronchitic. 
main bronchus was significantly higher than in the segmental bronchi $(p<0.0005)$.

The variation of the components at different sites is in general similar to that seen in the normal subject. ${ }^{4}$

\section{Symptomatology: the effects of smoking}

Analysis of the various parameters in Table 2 revealed no sex difference, but there were significant difference between smokers and non-smokers. Overall, subjects who did not smoke experienced their first symptoms 8.5 yr later than their smoking contemporaries $(p<0.025)$, were able to tolerate seven years more total exposure before giving up work $(p<0.0125)$, and died $10 \mathrm{yr}$ later $(\mathrm{p}<0.0005)$. The corresponding figures for women non-smokers and smokers were $12.4,8.8$ and 10.5 years respectively $(p<0.025$ in each case). The period from onset of symptoms to death was similar in the smoking and non-smoking subjects. There was no significant difference in the percentage of the tissue components at any site in the smoking and non-smoking groups. No correlation could be demonstrated between the tissue percentages and any of the parameters in Table 2.

\section{Discussion}

The results of this investigation show that in the named bronchi of byssinotics the proportions of gland, muscle and cartilage are increased. The figures are on the whole similar to those found in patients with chronic bronchitis ${ }^{5}$ and fibrosing alveolitis: ${ }^{4}$ there are minor differences, which although statistically significant, are of doubtful significance otherwise. The pattern of variation in the proportions of the various components at different sites broadly follows that seen in other conditions. ${ }^{45}$

Our earlier study ${ }^{2}$ indicated that in byssinotics there was an increased proportion of gland and muscle in lobar but not segmental bronchi, whereas in this investigation such changes were found in both groups of airways. The probable reason for this disparity is that in 1975 we examined only the lobar and basal segmental bronchi, using a point counting technique. With modern electronic equipment we have now been able to measure the tissue proportions of many more airways with a much greater degree of accuracy.
Since the publication of our previous paper, workers in North Carolina ${ }^{3}$ have demonstrated an association between glandular hyperplasia and exposure to cotton dust, and have also stressed the importance of cigarette smoking. But the changes in Lancashire byssinotics must be interpreted with caution. The majority of our subjects had not worked in the cotton industry for many years, and had lived under poor socioeconomic circumstances in an area with a very high incidence of chronic bronchitis. And although in common with other investigators, ${ }^{13}$ we found that smoking has a deleterious effect on the natural history of the disease, there appears to be no morphological difference between smoking and nonsmoking byssinotics.

The increased percentage of muscular and glandular tissue in the named bronchi of byssinotics from Lancashire, then, is non-specific, and cannot be attributed to cotton dust alone. Moreover physiological measurements suggest that cotton dust affects the smaller bronchi, ${ }^{1}$ and it may be that changes in the larger bronchi are secondary. The reason for the increased percentage of cartilage in byssinotics and other chronic respiratory diseases is uncertain, and requires further investigation.

We are grateful to Mrs Ruth Fry for her secretarial assistance. This investigation was supported by a grant from the National Cotton Council of America.

\section{References}

${ }^{1}$ Parkes WR. Occupational lung disorders. London: Butterworth, 1982.

${ }^{2}$ Edwards C, Macartney J, Rooke G, Ward F. The pathology of the lung in byssinotics. Thorax 1975;30:612-23.

${ }^{3}$ Pratt PC, Vollmer RT, Miller JA. Epidemiology of pulmonary lesions in nontextile and cotton textile workers: a retrospective autopsy analysis. Arch Environ Hlth 1980;35:113-8.

${ }^{4}$ Edwards C, Carlile A. The larger bronchi in cryptogenic fibrosing alveolitis: a morphometric study. Thorax 1982;37:828-33.

${ }^{5}$ Carlile A, Edwards C. Structural variation in the named bronchi of the left lung: a morphometric study. Br J Dis Chest 1983; 77:344-8.

Requests for reprints to: Dr C Edwards, Department of Histopathology, East Birmingham Hospital, Bordesley Green East, Birmingham B9 5ST, England. 